\title{
MODELS OF FINANCING OF HIGHER EDUCATION INSTITUTIONS IN FOREIGN COUNTRIES
}

\author{
Lesia Leshanych ${ }^{1}$, Iryna Miahkykh ${ }^{2}$, Mariana Shkoda ${ }^{3}$
}

\begin{abstract}
The aim of the article is to study the problems of reforming the system of financing higher education in conditions of compliance with world quality standards of education. Besides, another aim of the article is also to substantiate of the perspectives of their use in Ukraine, on the basis of analysis of the main foreign models of higher education institutions financing. The subject of the study is the financing model of institutions of higher education in foreign countries. Methodology. The research is based on a comparative analysis of funding systems for higher education institutions in Ukraine and in foreign countries. The advantages and disadvantages of different systems of the financial provision of higher education are determined based on the analysis of the peculiarities of financing higher education institutions in Germany, USA, UK, Sweden, Norway, and Australia and in some other countries. On the basis of a comparative legal research of certain provisions of Ukrainian legislation, the possibilities and limits of the application of positive foreign experience in this field are defined. The results of the study showed that the financing of higher education at the expense of state funds should be directed only to the needs of the state. And the state, in its turn, should provide graduates with jobs that will help reduce unemployment among them. Currently, there is a partial improvement of diversification of funding sources in Ukraine. We mean that the provision of the status of a non-profit organization will give the first impetus to the formation of contract relations between higher education institutions and private organizations and will improve their financial position. The implementation of the foreign experience will make financing more transparent and will give an opportunity to distribute it according to the quality criteria of providing educational services. Practical impact. Experience of the developed economies and the analysis of the existing condition of financing of educational institutions of Ukraine allow defining the priority directions of improvement of a system of financing of the higher education. As the budget of Ukraine is not able to compensate all needs for financial resources of higher educational institutions, it is necessary to encourage private investments into education, training, and high technologies more actively. Besides, conducting researches, the international consultations, modelling and discussion of the schematic diagram and funding mechanism for the higher education in Ukraine is also expedient. Correlation/originality. Conducting a comparative analysis of financing models of higher education institutions in Ukraine and foreign countries is the basis for developing the most promising directions for the development of domestic legislation in this field.
\end{abstract}

Key words: institutions of higher education, autonomy, financing of education, foreign experience, financing models.

JEL Classification: 122, 123

\section{Introduction}

The tasks of providing Ukraine with professional personnel are in a number of strategic since the security and socio-economic progress of the country depend on their solution. State policy in the field of higher professional education, defining the directions of its development, creates the basis for the diversification of the composition of highly qualified specialists.

Byjoining the Bologna Convention, Ukraine has begun transforming the system of training highly qualified personnel to ensure its compliance with world quality standards of education, changing the composition and structure of higher education institutions, giving them the freedom to choose sources of finance, as well as the possibility of commercializing their core activities. In particular, it is determined that financing of state institutions of higher education is carried out at the expense of the state budget funds on the terms of a state order for payment for training services for specialists, scientific and pedagogical staff, and at the expense of other sources not prohibited by law, in compliance with the principles of targeted and efficient use of funds, publicity and transparency in decision making (Zakon Ukrainy «Pro vyshchu osvitu»).

\footnotetext{
Corresponding author:

${ }^{1}$ Uzhhorod National University, Ukraine.

${ }^{2}$ Kyiv National University of Technologies and Design, Ukraine.

${ }^{3}$ Kyiv National University of Technologies and Design, Ukraine.
} 
There is a need to develop an effective system of financing higher education aimed at ensuring the proper training of specialists, which will provide:

- creation of a transparent market for educational services;

- the attraction of significant additional financial instruments, including credit resources, under state guarantees;

- the transition from the ideology of subsidies to the ideology of investing in education;

- stimulation of constant motivation of students to qualitative education;

- the attraction of funds from the banking sector to preferential student loans.

The main instrument of the new model of financing higher education should be the creation of a personalized system of access to financial resources for the implementation of individual human educational development (Postanova Verkhovnoi Rady Ukrainy).

The experience of the leading countries of the world shows that one of the most important levers of management of this process is the state financing mechanism of higher education. The foreign practice of financing educational institutions has a long history, is characterized by flexibility and market orientation in the selection of forms, methods, and tools. Analysis and implementation of a positive foreign experience in this area will allow Ukraine to continue its reforms in line with the strategic state priorities of financing Ukrainian state educational institutions of higher education.

The practice of state financing of education does not remain constant and unchanged, constantly changing internal and external conditions of functioning of the industry dictate the need to improve the entire financial mechanism: the tax base, the normative definition of funding, the system of intergovernmental fiscal relations. The urgent need is to create a transparent, targeted, stimulating nature of financing of budget spheres and education, including the strengthening of the elements of responsibility and the reduction of the influence of subjective factors (manual guidance) on the process of making financial decisions in the education system, which determines the relevance of our study.

Issues of education, sources of its funding and effectiveness have always been the focus of attention of scholars. The theory and practice of financial provision of higher education have been repeatedly investigated by such domestic scholars as V. Andrushchenko, J. Beskid, T. Bogolib, E. Boyko, V. Bukovinsky, O. Grishnov, I. Kalenyuk, K. Korsak, V. Kutsenko, D. Kucherenko, O. Martynyuk, M. Shavirin, L. Shevchenko. Also noteworthy is the research on the financing of the educational system of Western economic schools, in particular, T. Arnold, E. Dinnson, T. Moe, H. Mayer, K. Nordstrom, M. Friedman, J. Schumpeter et al. The works of these scholars form the basis for further developments and are the theoretical basis of the study.
The purpose of the paper is to study the problems of reforming the system of financing higher education in conditions of achieving compliance with world standards of quality of education and on the basis of analysis of the main foreign models of financing higher education institutions substantiation of the prospects of their use in Ukraine.

\section{The main material}

The key problem in improving the financing of the education system (and not just it) is to increase the efficiency of public expenditures, which leads to the search for new approaches and mechanisms. It is obvious that this process must foresee, firstly, a clear idea of what and for what purposes the state funds come from. Secondly, the methods and forms of allocation of funds. Thirdly, the definition of the status of the institution receiving budget financing, which also covers issues of its authority and responsibility for the results of activities. It is the unclear understanding of these issues that is based not on inefficiency but rather on the lack of internal logic of directing the budget process towards transparency and efficiency (Kaleniuk, 2017).

In recent years, in world practice, there has been a change in the funding of public higher education systems and mechanisms for allocating budget funds between higher education institutions. This is due to the sharp increase in student contingents and the limited budget resources, which requires increased use of public funds and the involvement of various non-state sources. To a large extent, the transformation of the forms and mechanisms of financing is influenced by the change in the nature and content of higher education in connection with the need for the formation of individual educational programs of education, diversification of their content, terms and forms of delivery of educational services to the consumer.

In world practice, funding for higher education is costly. In the United States, higher education is the fifth in the monetary calculation of the US economy's export, which sometimes exceeds the amount of arms exports. In Australia, the educational sector is the third largest source of budget revenues in the country's economy. In 2014, the Canadian government has recognized international education as a key factor in creating new jobs and improving welfare and plans to double the number of foreign students to 450,000 by 2022. This will increase the cost of foreign students in the country to $\$ 16.1$ billion and will create in Canada, at least, 86.5 thousand new jobs.

According to the latest UNESCO data (2006-2012), the top 10 countries with the highest share of GDP spent on education are Lesotho, Cuba, Timor-Leste, Denmark, Moldova, Djibouti, Namibia, Cyprus, Botswana, and Iceland (Kharlamova, 2017).

An analysis of foreign experience clearly shows that in most countries any serious reorganization in this area 
is preceded by a modernization of the current model of its management in the direction of strengthening the autonomy of universities in the issues of recruitment of students and the management of available resources. One of the most important directions is the strengthening of financial autonomy of higher education institutions both in attracting extrabudgetary funds and in using material and financial resources.

The value of autonomy for universities is not "academic freedom" but the ability and the right to determine their own lines of action without undue interference by the state, although such autonomy is relative since it calls for increased attention from society and state control. However, autonomy should not be perceived as the complete independence of universities from the state. Firstly, the provision of high financial and administrative autonomy to higher education is accompanied by an increase in the quality control of education. Secondly, the state everywhere continues to finance at least $70 \%$ of the higher education budgets (Laryonova, 2005).

It should be noted that the autonomy of higher education is understood as increasing the financial and administrative independence of universities from the state, which manifests itself in increasing the autonomy of higher education in all spheres of management - from personnel and administrative-financial policy to student planning, the content and volume of training courses, and the identification of priority areas of scientific researches.

The financial autonomy of universities is the main benchmark in the world practice of an educational organization, despite the fact that in many countries the state still has a dominant role in the financial provision of higher education. The increase of financial autonomy of higher educational institutions is indicated by a sharp reduction of the share of state financial participation. For example, in Germany and the UK, the requirements of higher education institutions to expand their autonomy are linked to the state administration with a reduction of their funding from the state budget, stating that if they want more autonomy, then they have to learn how to make money.

For example, in the United Kingdom, the Special Education Board for the financing of higher education institutions in the UK (HEFCE) calculates the volume of financial support for current activities on the basis of four groups of specialties: medical and veterinary specialties; exact and natural sciences, technological and engineering specialties; specialties requiring laboratory equipment; specialties that do not require laboratory equipment.

In turn, in Germany, each of the 16 Länder of Germany has its own Ministry of Education, which manages all institutions in its territory. In order to coordinate programs and curricula, national structures have been established, in particular since 1969, the Federal Ministry of Education (Hryshchenko, 2015).
In the EU, university autonomy is one of the main issues. When establishing the European Association of Universities in 2001 autonomy with accountability was identified as the most important principle. Subsequently, the four distinct types of autonomy were clearly identified in the 2007 Lisbon Declaration: Academic (decision on educational activities), financial (financing receipt and distribution, decision to pay tuition, use of profits, etc.), organizational (determining university structure, contracting, rector's election, etc. managers), and staffing (recruitment, remuneration, and personnel careers).

For each type of autonomy, indicators are set according to which its level is determined. For example, for financial autonomy, the following indicators have been set: duration and type of financing, the possibility of profit, the ability to receive loans, the ability to own real estate, the ability to set the level of payment for local and foreign students.

In other countries, including the United States, academic freedom is guaranteed by high financial autonomy, which forms its funds from various government (central, regional, and local) agencies and other sources.

Here is the so-called principle of budgeting, which allows you to focus on the result of activities within the framework of the state task and the state contract. An important experience for Ukraine is the financial support of the highest university potential in the US through the mechanism of the endowment, which of the 22 US higher education institutions ranked 1st - the 30th place under the Shanghai rating, in 2015 was $85 \%$ in 13 private establishments (Savchenko, Chumak, 2017).

In the member countries of the Organization for Economic Cooperation and Development (OECP), where the state has traditionally controlled the financial provision of educational activities, it is now recognized the superiority of the market mechanism in comparison with the administrative regulation of supply and demand for different forms of training provided to different groups of consumers.

In this regard, the state's attention is focused on the reform aspects of governance, strategy and prioritization, while the operational activities of universities are paying less and less attention. In some countries, including in Ukraine, this is reflected in the establishment of agencies to monitor the quality of teaching and research.

Thus, the Law of Ukraine "On Higher Education" provides for the creation and functioning in Ukraine of an independent permanent collegial body authorized to implement state policy in the field of quality assurance in higher education, - the National Agency for the Quality Assurance of Higher Education, whose members are elected by congresses of representatives of higher educational institutions of various forms of ownership, student self-government bodies of higher educational establishments, national and branch academies of sciences and employers. 
In particular, the National Agency has the following powers:

- forms requirements for the system of quality assurance in higher education, develops the provisions on accreditation of educational programs, and submits it to the Ministry of Education for approval;

- analyses the quality of educational activities of higher educational institutions;

- conducts a licensing examination, prepares an expert opinion on the possibility of issuing a license for conducting educational activities in the field of higher education;

- coordinates the developed educational standards of educational activity and standards of higher education in each specialty;

- forms a single database of higher education institutions specializing in the training of higher education graduates at each level of higher education;

- decides on accreditation or refusal to accredit the relevant educational program;

- forms the criteria for assessing the quality of educational activities, in particular, scientific achievements, higher education institutions, which may include ratings of higher education institutions;

- submits proposals for granting the higher educational institution a national status in accordance with the procedure and according to the criteria established by the Cabinet of Ministers of Ukraine;

- participates in the procedure established by law in the formation of indicators of a state order for the training of specialists with higher education at higher levels of higher education and specialties, taking into account the medium-term forecast of the needs of specialists in the labour market, etc. (Postanova Kabinetu Ministriv Ukrainy).

In OECP member countries, central government usually controls certain points in the higher education system, including setting tuition fees or issuing permissions for tuition fees, giving universities a significant degree of freedom in shaping academic structures, curricula, and staffing. Methods of financing universities have undergone significant changes. Funds are provided to universities on a block grant basis, rather than through a detailed transfer of budget items. There is also a clear tendency to enter or increase the level of payment for tuition, budgeting, result-oriented, and targeted programs. These changes accompanied the strengthening of autonomy and simplification of reporting in the university administration. At the same time, the development of certain forms and methods of attracting funds from extrabudgetary sources depends on many circumstances that are dictated both by the possibilities of a particular higher education and by state policy.

In conditions of higher education autonomy, the state stimulates the effective use of their financial resources and property, creates conditions for the distribution of income received for educational purposes. The basis of financial autonomy of universities in the leading countries of the world is the following principles:

- transition to flexible financing, payment for results (and other schemes);

- introduction of a more formalized system than before for scientific and educational activities;

- the distinction between permanent (guaranteed) and variables (on the efficiency of work) of government sources of financing. The guaranteed source of funding usually provides adequate provision (including pay) for the educational process, taking into account the medium-term, and sometimes the long-term perspective;

- distribution of funding flows for studies and research. In some countries, universities have the right to independently distribute received funds, while the funds for training are guaranteed, and for research variable flow;

- diversification and fragmentation of funding for each individual university and even for individual departments, units, and laboratories;

- use of financial intermediaries, with the exception of the transfer of a guaranteed (permanent) part of state subsidies.

Financial autonomy and the status of a legal entity allow the university to obtain the right to create and operate other (except for property) funds, which are formed at the expense of money, other donations, shares, and other types of securities.

In international practice, up to 4,000 funding schemes for universities are distinguished, differing in terms of the degree of state coverage of higher education costs; the mechanism of selection of potential students in high competition; inclusion in the system of financing along with state non-state universities; coverage of vouchers of the higher education system; the level of independence of universities in setting the price of education; priorities for children from disadvantaged or low-income families, etc.

Summarizing the foreign practice of financing higher education, we will try to identify the main models of financing higher education, the delimitation of which is conditional, as in most countries of the world are used combined options to provide higher education financial resources.

Model 1. Includes two interconnected models:

1.1. The financing is focused on needs;

1.2. Acquisition by the state of educational services for certain purposes.

Model 2: funding of higher education, based on the results of their work.

Model 3: financing, which is carried out directly by consumers of educational services and oriented to the demand and internal needs of the institution of higher education. 
Models of the first type are free of state higher education. Model 1.1 stipulates the obligation of higher education to train specialists with the qualifications necessary from a social point of view. In this case, the cost of training is set and agreed in advance; payment is made at the expense of the state budget. Such a model is valid for the countries of Southern, Central and Eastern Europe (including Ukraine), Africa, and Latin America.

Preference of Model 1.1 is that simultaneously the efficiency of using budget funds is increased and the expenses of the state are minimized. However, the relevance of the planned training to the needs of the labour market depends on the accuracy of the relevant forecasts of the state.

Model 1.2 envisages the participation of universities in competitions for obtaining a state order for the training of specialists, which ensures an efficient allocation of state tasks and reduces state expenditures. The order is received by the higher educational institution, whose educational services correspond to the conditions of the competition as much as possible, and the expenses for training are optimal.

In general, financing of the first type is characterized by a rather low degree of autonomy, as the use of financial resources is clearly controlled by public authorities.

The second type financing model is focused on the status of higher education, involves the allocation of public funds, depending on the results of its activities. The amount of funding is determined by the number of graduates, students admitted to the first year, the results of controlling knowledge of students, the complexity of training courses, the number of defended dissertations, etc.

Such models are implemented in Romania, Denmark, and the United Kingdom. In Sweden and the Netherlands, universities are funded on the basis of the awarded degrees and a positive assessment of their activities. The possibilities of using such a financing model for Ukraine are also being actively discussed.

The positive features of this model are the expansion of the authority of higher education in financial and administrative management. But the funding of higher education by "status" indicators provides the government with an effective management tool, while the Ministry of Education monitors the quality of education.

The third type financing model is aimed at realizing labour market needs, provides for the payment of educational services by direct consumers, and focuses on the demand and internal needs of an educational institution. This model uses government commitments, which are transmitted in the form of coupons, certificates (vouchers) to direct consumers of educational services. The significant constraint for the learner - the validity of the voucher.
In many countries, fees for higher education have been introduced by implementing a variety of third-party schemes (Australia, Austria, Brazil, Hungary, China, Kenya, New Zealand, Tanzania, etc.). In some of them, the state allows higher education to count a certain percentage of students based on full tuition fees. In this case, it is enough to get the minimum number of points to start training. In Australia, a fee is accepted for a fee of up to $25 \%$ of students from 1998, in China - since 1988, in Hungary - since 1997.

The benefits of financing education in this model are, firstly, in expanding autonomy in higher education enrolment courses, education planning and funding; and secondly, in conjunction with funding based on vouchers with payment by the students themselves.

\section{Conclusion}

As a result of the analysis of foreign experience in financing higher education, the following conclusions can be drawn: firstly, the cost of higher education should grow faster than the state funding that is provided to support it. Secondly, universities need a wider set of financial security instruments in an autonomous environment. Thirdly, corporate and private finance must be involved in the reimbursement of education costs. Fourthly, universities should manage their finances and assets more effectively to ensure longterm financial sustainability. Fifthly, the possibility of choosing different funding schemes allows the consumer of educational services to find the best option for providing financial investments in their own education, and higher - to provide additional cash inflows.

In the Ukrainian practice of financing education, it is advisable to combine different models of financial provision of higher education institutions since the advantages of each of the models considered are irrefutable in terms of their impact on the economy and the social sphere. The execution of a state order, financing higher than the performance indicators, the impact of the labour market - the actual tasks for the domestic high school.

The need for a transition to flexible financing by the state is determined by the needs of the Ukrainian labour market, which develops in accordance with global trends: the strengthening of migration processes and competition from foreign specialists. Therefore, for Ukraine, particular interest is the use of the model, oriented to the status of higher education, as it stimulates the educational institution to link its capabilities with the demands of employers. In connection with the transformation of state universities into autonomous institutions, the use of foreign experience in financing education in Ukrainian practice will allow the more rational use of public funds allocated for the educational sphere and actively implementing innovative educational financing instruments. 


\section{References:}

Zakon Ukrainy «Pro vyshchu osvitu» vid 01.07.2014 [The Law of Ukraine "On Higher Education" of 01.07.2014]. URL: http://zakon.rada.gov.ua/laws/show/1556-18

Postanova Verkhovnoi Rady Ukrainy «Pro Rekomendatsii parlamentskykh slukhan na temu: «Pro stan ta problemy finansuvannia osvity i nauky v Ukraini» vid 12 lypnia 2017 № 2133-VIII [Resolution of the Verkhovna Rada of Ukraine "On Recommendations of the Parliamentary Hearings on the theme "On the State and Issues of Financing Education and Science in Ukraine "dated July 12, 2017 № 2133-VIII]. URL: http:/ /zakon.rada.gov.ua/ laws/show/2133-19

Kaleniuk, I. S. (2017). Napriamy transformatsii mekhanizmiv finansuvannia osvity v suchasnomu sviti [Directions of transformation of financing mechanisms of education in the modern world]. Demohrafia ta sotsialna ekonomika, $1(29), 24-36$.

Kharlamova, H. (2017). Brytanska model finansuvannia vyshchoi osvity: uroky dlia Ukrainy [British Higher Education Financing Model: Lessons for Ukraine]. Visnyk Kyivskoho natsionalnoho universytetu imeni Tarasa Shevchenka. Ekonomika, 5(194), 58-66.

Laryonova, M. V. (2005). Aktualnue voprosu razvytyia obrazovanyia v stranakh OESR: ucheb. Posobye [Current issues of education development in OECD countries: studie book]. Moskva: Yzdat. dom HU VShE.

Hryshchenko, I. M. (2015). Teoretyko-metodolohichne obgruntuvannia efektyvnykh finansovo-ekonomichnykh modelei rozvytku vyshchoi shkoly: monohrafiia [Theoretical and methodological substantiation of effective financial and economic models of higher education development: monograph]. Kyiv.

Savchenko, I. H., Chumak, O. V. (2017). Modernizatsiia derzhavnoho mekhanizmu finansuvannia vyshchoi osvity $\mathrm{v}$ umovakh yii reformuvannia [Modernization of the state financing mechanism of higher education in conditions of its reformation]. Teoriia ta praktyka derzhavnoho upravlinnia, (58), 1-6.

Postanova Kabinetu Ministriv Ukrainy «Pro utvorennia Natsionalnoho ahentstva iz zabezpechennia yakosti vyshchoi osvity» vid 15 kvitnia 2015 r. № 244 [Resolution of the Cabinet of Ministers of Ukraine "On the Establishment of the National Agency for the Quality Assurance of Higher Education" dated April 15, 2015, No. 244]. URL: http://zakon.rada.gov.ua/laws/show/244-2015-\%D0\%BF/paran15\#n15 